\title{
Seasonal variation of aliphatic amines in marine sub-micrometer particles at the Cape Verde islands
}

\author{
C. Müller ${ }^{1}$, Y. Iinuma ${ }^{1}$, J. Karstensen ${ }^{2}$, D. van Pinxteren ${ }^{1}$, S. Lehmann ${ }^{1}$, T. Gnauk ${ }^{1}$, and H. Herrmann ${ }^{1}$ \\ ${ }^{1}$ Leibniz-Institut für Troposphärenforschung (IfT), 04318 Leipzig, Germany \\ ${ }^{2}$ Leibniz-Institut für Meereswissenschaften (IFM-GEOMAR), 24105 Kiel, Germany
}

Received: 12 June 2009 - Published in Atmos. Chem. Phys. Discuss.: 9 July 2009

Revised: 20 November 2009 - Accepted: 27 November 2009 - Published: 21 December 2009

\begin{abstract}
Monomethylamine (MA), dimethylamine (DMA) and diethylamine (DEA) were detected at non-negligible concentrations in sub-micrometer particles at the Cap Verde Atmospheric Observatory (CVAO) located on the island of São Vicente in Cape Verde during algal blooms in 2007. The concentrations of these amines in five stage impactor samples ranged from $0-30 \mathrm{pg} \mathrm{m}^{-3}$ for MA, $130-360 \mathrm{pg} \mathrm{m}^{-3}$ for DMA and $5-110 \mathrm{pg} \mathrm{m}^{-3}$ for DEA during the spring bloom in May 2007 and 2-520 $\mathrm{pg} \mathrm{m}^{-3}$ for MA, 100-1400 $\mathrm{pg} \mathrm{m}^{-3}$ for DMA and $90-760 \mathrm{pg} \mathrm{m}^{-3}$ for DEA during an unexpected winter algal bloom in December 2007. Anomalously high Saharan dust deposition and intensive ocean layer deepening were found at the Atmospheric Observatory and the associated Ocean Observatory during algal bloom periods. The highest amine concentrations in fine particles (impactor stage 2, 0.14-0.42 $\mu \mathrm{m}$ ) indicate that amines are likely taken up from the gas phase into the acidic sub-micrometer particles. The contribution of amines to the organic carbon (OC) content ranged from $0.2-2.5 \% \mathrm{C}$ in the winter months, indicating the importance of this class of compounds to the carbon cycle in the marine environment. Furthermore, aliphatic amines originating from marine biological sources likely contribute significantly to the nitrogen content in the marine atmosphere. The average contribution of the amines to the detected nitrogen species in sub-micrometer particles can be non-negligible, especially in the winter months $(0.1 \% \mathrm{~N}-$ $1.5 \% \mathrm{~N}$ in the sum of nitrate, ammonium and amines). This indicates that these smaller aliphatic amines can be important for the carbon and the nitrogen cycles in the remote marine environment.
\end{abstract}

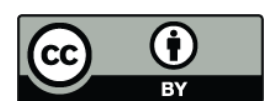

Correspondence to: $\mathrm{H}$. Herrmann (herrmann@tropos.de)

\section{Introduction}

Marine aerosol plays an important role in the Earth system, especially in the climate and atmospheric chemistry, contributing significantly to a global aerosol burden and influencing both direct and indirect radiative forcing and a variety of chemical processes (ICCP, 2007). It is known that marine aerosol in sub-micrometer size range is mainly formed by gas-to-particle conversion of sulfuric acid (Kulmala, 2003; Kulmala and Kerminen, 2008). It has been shown that a bubble bursting process can produce a wide spectrum of particles ranging from a sub-micrometer particle (O'Dowd and Smith, 1993; Mårtensson et al., 2003; Resch and Afeti, 1992) to a coarse particle (Blanchard, 1954; Knelman et al., 1954; Woodcock et al., 1953). It is believed that ammonium sulfate and sodium chloride produced by these two processes account a large fraction of the mass in marine aerosols (Arimoto et al., 1992; Fitzgerald, 1991; Raemdonck et al., 1986). In addition, a non-negligible amount of organic material is shown to contribute to the particle mass in marine aerosols (Cavalli et al., 2004; Hoffman and Duce, 1974, 1976; O'Dowd et al., 2004). Model studies have estimated that the contribution of organic carbon to marine aerosol is in a similar order of magnitude to anthropogenically influenced particle burden globally (Bond et al., 2004; Cooke et al., 1999; Roelofs et al., 2008; Sprackeln et al., 2008). The organic mass fraction of the marine aerosol contains water soluble organic carbon (WSOC) and water insoluble organic carbon (WISOC) (Cavalli et al., 2004; O'Dowd et al., 2008; Facchini et al., 2008b; Yoon et al., 2007) with a WISOC fraction as high as $60 \%$ in sub-micrometer particles (Cavalli et al., 2004; O'Dowd et al., 2008; Yoon et al., 2007). So far the chemical composition of the WISOC mass fraction and the transfer of the organic material into the particle phase are not well known. On the other hand, the chemical composition of the WSOC fraction is more comprehensively investigated. For example, different field studies have shown the presence

Published by Copernicus Publications on behalf of the European Geosciences Union. 
of a wide range of organic compounds such as carboxylic acids (Kawamura and Gagosian, 1987, 1990; Kawamura and Sakaguchi, 1999; Matsumoto and Uematsu, 2005; Kawamura and Usukura, 1993; Kuznetsova et al., 2005; Mochida et al., 2003a, b; Wang et al., 2006), fatty acids (Mochida et al., 2003b; Sicre et al., 1990), amino acids (Matsumoto and Uematsu, 2005; Kuznetsova et al., 2005) and aliphatic amines (Facchini et al., 2008a; Gibb et al., 1999).

The organic material in the remote marine environment is thought to originate mainly from the marine biochemistry. One important primary mechanism to form organic marine particles is the bursting of surface ocean film during the bubble bursting process. In addition to the primary process, secondary mechanisms play an important role in transferring organic material into the particle phase. Such process includes the condensation of semivolatile gas phase compounds from the photooxidation of trace gases. Theoretical model calculations suggest that isoprene oxidation contributes about $2-30 \%$ to the secondary organic aerosol (SOA) formation in the marine atmosphere (Arnold et al., 2009; Healy et al., 2008; Gantt et al., 2009). Another process is the reactive uptake of gas phase species into the particle phase. Facchini et al. (2008a) have recently found considerable concentrations of dimethylamine and diethylamine in sub-micrometer marine aerosol collected in the North Atlantic region, demonstrating a potential importance of amines of biological origin for SOA formation. No clear explanation is given for the presence of high vapor pressure amines in sub-micrometer aerosol though thermodynamic calculations suggest that amines displace ammonium in ammonium sulfate, resulting in the formation of stable aminium sulfate salts in sub-micrometer marine aerosol (Kurten et al., 2008; Barsanti et al., 2009). Indeed, good correlations are reported between the concentrations of amines, non-sea-salt sulfate (NSS) and methanesulfonic acid (MSA), suggesting the emission of amines by phytoplankton and subsequent reactions with sulfate aerosol, leading to aminium salt formation (Facchini et al., 2008a). Moreover, different field studies performed in the marine environment have shown the presence of aliphatic amines in the gas phase (Gibb el al., 1999; van Nest and Duce, 1987), the aqueous phase (rain and seawater) (Gibb et al., 1999; van Nest and Duce, 1987) and the particle phase (Cornell et al., 2001; Facchini et al., 2008a; Gibb et al., 1999; Mopper and Zika, 1987). In addition, the amine concentrations measured over the northern Atlantic showed a seasonal variation, indicating that the production of amine is most likely influenced by the primary biological productivity of phytoplankton and therefore available nutrients in the ocean (Facchini et al., 2008a). However, information on their temporal and spatial variations in the remote marine environment is still not well understood.

In the present study, we report the first time series of alkyl amine concentrations and their mass size distributions in marine aerosol collected at the Cape Verde Atmospheric Observatory in the tropical East Atlantic Ocean between May 2007

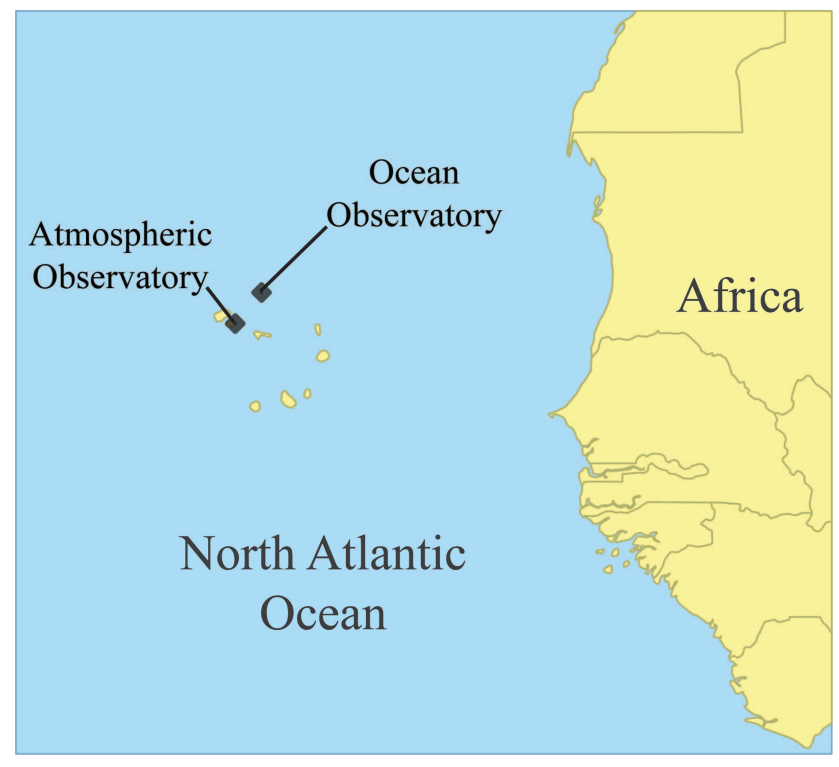

Fig. 1. Cape Verde Atmospheric Observatory (CVAO) $\left(16^{\circ} 51^{\prime} 49^{\prime \prime} \mathrm{N}, 24^{\circ} 52^{\prime} 02^{\prime \prime} \mathrm{W}\right)$ at São Vicente and the Cape Verde Ocean Observatory $\left(17^{\circ} 35^{\prime} 39^{\prime \prime} \mathrm{N}, 24^{\circ} 15^{\prime} 120^{\prime \prime} \mathrm{W}\right)$.

and June 2008. A significant seasonal difference in the concentrations of amines is discussed in terms of air mass origins, primary marine productivity of the region and the influence of Saharan dust deposition.

\section{Experimental}

\subsection{The Cap Verde Atmospheric Observatory (CVAO)}

The Cap Verde Observatory consists of both atmospheric and oceanic sites situated at the western edge of the Northeast Tropical Atlantic upwelling region off the coast of West Africa (Fig. 1). The observatory sites have been designed to be representative for the oceanic condition in the Northeast trade wind zone. The atmospheric observatory is located at the lee side of the northeast coast of São Vicente island, facing directly the ocean $\left(16^{\circ} 51^{\prime} 49^{\prime \prime} \mathrm{N}, 24^{\circ} 52^{\prime} 02^{\prime \prime} \mathrm{W}\right)$. The oceanic site $\left(17^{\circ} 35^{\prime} 39^{\prime \prime} \mathrm{N}, 24^{\circ} 15^{\prime} 120^{\prime \prime} \mathrm{W}\right)$ is located about 60 nautical miles to the northeast of the atmospheric site in $3600 \mathrm{~m}$ water depth. The location was carefully chosen to be in deep waters and with minimal influence of the island.

\subsection{Sampling}

The sampling at the atmospheric site was performed at the top of a $30 \mathrm{~m}$ sampling tower to minimize the influence of sea spray. A high volume (HV) sampler equipped with a $\mathrm{PM}_{10}$ inlet (DHA-80, Digitel Elektronik AG, Hegnau, Switzerland) was used to collect the aerosol samples during a one year field campaign. The samples were collected on pre-combusted quartz fiber filters $\left(110^{\circ} \mathrm{C}\right.$ for $24 \mathrm{~h}, 150 \mathrm{~mm}$, 
Munktell, Falun, Sweden) at a flow rate of $500 \mathrm{~L} \mathrm{~min}^{-1}$. The samples collected between 10 May 2007 and 15 June 2008 were chosen for this study. Additionally, size segregated aerosol samples were collected during two intensive campaigns (17 May-14 June 2007 and 28 November 2007-5 January 2008) using a five stage Berner-type impactor with 50\% cut-off sizes at $0.14,0.42,1.2,3.5$ and $10 \mu \mathrm{m}$. The samples were collected on pre-combusted aluminum foils $\left(300^{\circ} \mathrm{C}\right.$, $24 \mathrm{~h}$ ) at a flow rate of $75 \mathrm{~L} \mathrm{~min}^{-1}$. Standard sampling duration was $48 \mathrm{~h}(72 \mathrm{~h}$ for several samples) and $24 \mathrm{~h}$ during the intensive campaigns. The samples were stored frozen $\left(-20^{\circ} \mathrm{C}\right)$ until analysis.

The oceanic observatory consists of a steel wire mooring with the autonomous recording instruments to measure relevant physical and biogeochemical variables at multiple, predefined depths. Of interest in the present study is data from five SeaBird SBE 37 temperature recorders sampled at $27 \mathrm{~m}$, $49 \mathrm{~m}, 68 \mathrm{~m}, 90 \mathrm{~m}$, and $116 \mathrm{~m}$ water depth for the period of July 2006-February 2008 and with a temporal resolution of $30 \mathrm{~min}$. This temperature time series data have been supplemented with Advanced Microwave Scanning Radiometer (AMSR-E) Version 5 sea-surface temperature (SST) data, available in daily resolution. In addition, level 3 near surface chlorophyll- $a$ (Chl- $a$ ) data derived from MODIS satellite ocean color retrievals data have been used as a proxy for ocean bio-productivity.

\subsection{Chemical analysis}

\subsubsection{Methanesulfonic acid (MSA), oxalic acid, inorganic anions and cations}

A portion of the quartz fiber filter or aluminum foil was cut and extracted in $2 \mathrm{~mL}$ Milli-Q grade water (Millipore, Massachusetts, USA). The water extract was filtered through a pre-cleaned syringe filter $(0.45 \mu \mathrm{m}$, Pall, New York, USA $)$ to remove insoluble materials. Anions including MSA and oxalic acid were determined using capillary electrophoresis with a UV-detector (CE-DAD) (Spectra Phoresis 1000, Thermo Separation Products, Waltham, MA, USA) and cations were determined using ion chromatography (IC) (Metrohm 690, Herisau, Switzerland). Detailed descriptions of the CE-DAD and IC methods are reported by Neusüß et al. (2000).

\subsubsection{Total organic carbon (TOC) content}

The total organic carbon (TOC) content was determined using a thermographic method (C-mat 5500, Ströhlein, Germany) described in Iinuma et al. (2007). Briefly, a part of the quartz filter or aluminum foil was cut and heated up $\left(690^{\circ} \mathrm{C}\right)$ under nitrogen atmosphere for the organic carbon and under oxygen atmosphere for the elemental carbon. The resulting $\mathrm{CO}_{2}$ was detected by NDIR (non-dispersive infrared) absorption and quantified by an external calibration with potassium hydrogen phthalate.

\subsubsection{Alkyl amines}

Another section of the quartz fiber filter or aluminum foil was cut and placed in a vial with L-norleucine ( $>99 \%$, Fluka, St. Louis, MO, USA) as an internal standard. The filter was extracted in $0.7 \mathrm{~mL}$ methanol for $10 \mathrm{~min}$ under ultrasonication. Afterwards the methanol extract was filtered through pre-cleaned syringe filter $(0.2 \mu \mathrm{m}$, Pall, NY, USA) to remove insoluble residuals. The extracted filter was washed twice with $0.5 \mathrm{~mL}$ methanol and the washing solution was added to the extracted solution after filtration. The extract was evaporated to about $10 \mu \mathrm{L}$ under a gentle stream of nitrogen at $10^{\circ} \mathrm{C}$. The resulting solution was derivatized with $10 \mu \mathrm{L}$ of 6-aminoquinolyl-N-hydroxysuccinimidyl carbamate (Waters AccQ.Tag ${ }^{\mathrm{TM}}$, Milford, MA, USA) after adding $20 \mu \mathrm{L}$ of $0.025 \mathrm{~N}$ sodium hydroxide solution. Afterwards the solution was heated at approximately $55^{\circ} \mathrm{C}$ for $10 \mathrm{~min}$. After cooling to room temperature, the solution was acidified with $10 \mu \mathrm{L} 0.5 \mathrm{~N}$ acetic acid. A high performance liquid chromatography system with UV detection (HPLC-UV, 1100 series, Agilent Technologies, Santa Clara, CA, USA) coupled to an electrospray ionization-ion trap mass spectrometer (ESI-ITMS, Bruker Daltonics, Bremen, Germany) was used for the determination of the amines. The separation was carried out on a Waters SunFire C18 RP column $(3.5 \mu \mathrm{m}, 2.1 \times 100 \mathrm{~mm})$ at $25^{\circ} \mathrm{C}$ using an eluent gradient program. The eluent composition was (A) $0.2 \%$ acetic acid in water and (B) $0.2 \%$ acetic acid in acetonitrile. The gradient was programmed as follows: $0 \% \mathrm{~B}$ for $10 \mathrm{~min}, 0 \% \mathrm{~B}$ to $5 \% \mathrm{~B}$ in $30 \mathrm{~min}, 5 \% \mathrm{~B}$ to $10 \% \mathrm{~B}$ in $15 \mathrm{~min}, 10 \% \mathrm{~B}$ to $15 \%$ $\mathrm{B}$ in $10 \mathrm{~min}, 15 \% \mathrm{~B}$ to $70 \% \mathrm{~B}$ in $12 \mathrm{~min}$ and held constant for $8 \mathrm{~min}$. The flow rate of the eluent was $0.2 \mathrm{~mL} \mathrm{~min}^{-1}$. The amines were detected with an UV detector at $254 \mathrm{~nm}$ and simultaneously with ESI-ITMS in the negative ion mode. Quantification was performed using the data obtained from ITMS analysis with six point quadratic calibration curves. The regression coefficients of the calibration curves were better than 0.999 for all standard compounds. All standard compounds used in this study are the highest grade commercially available (methylamine hydrochloride $\geq 98 \%$ (Sigma-Aldrich, St. Louis, MO, USA), dimethylamine hydrochloride 99\% (Sigma Aldrich, St. Louis, MO, USA), diethylamine hydrochloride 99\% (Sigma-Aldrich, St. Louis, MO, USA), morpholine $99.5 \%$ (Riedel de Haën, St. Louis, MO, USA)). Size segregated aliphatic amine concentrations were determined from the impactor stages 2, 3 and 4 , based on previous work that showed the highest amine concentrations in smaller than $1 \mu \mathrm{m}$ particles (Facchini et al., 2008a). Analytical figures of merits for the HPLC/ESIMS method used in this study can be found in Supplementary Information (http://www.atmos-chem-phys.net/9/9587/ 2009/acp-9-9587-2009-supplement.pdf). 


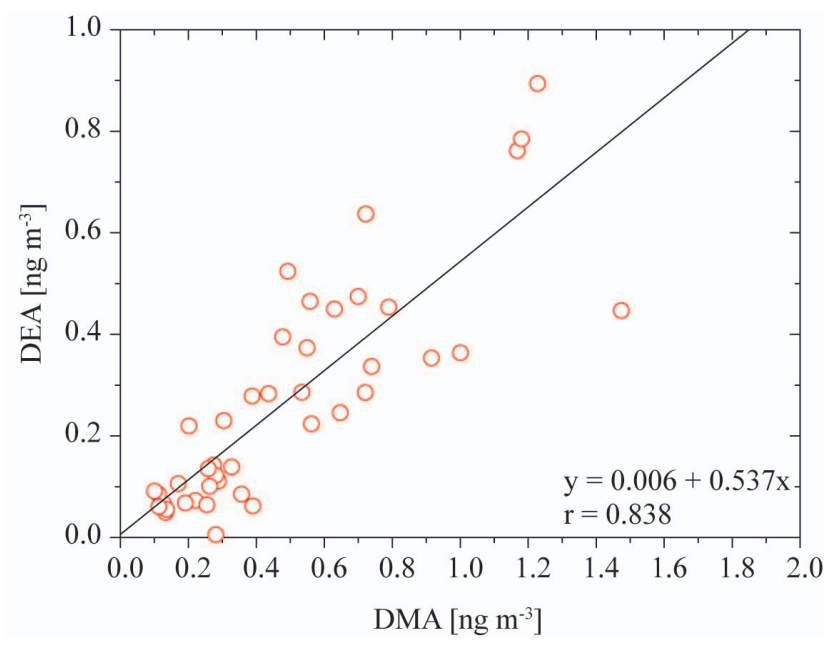

Fig. 2. Correlation of dimethylamine (DMA) and diethylamine (DEA) detected in the stage 2 Berner impactor samples.

\section{Results and discussion}

\subsection{Particle-phase aliphatic amines}

\subsubsection{Size-resolved impactor samples}

In the size resolved samples collected during the intensive campaigns (17 May-14 June 2007 and 28 November 20075 January 2008), the highest concentrations of amines were mostly found in stage 2 samples $(0.14-0.42 \mu \mathrm{m})$ except for a few days in which DMA and DEA were detected at higher concentrations in stage 3 and 4 samples. No morpholine (see Sect. 3.1.2) was detected in the impactor samples. This may be explained by an artifact formation in the acidic quartz fiber filter that absorbed the gas-phase amines (see Sect. 3.1.3). The size-segregated samples showed a good correlation between DMA and DEA $(R=0.80)$, similar to the HV samples (Fig. 2). MA followed similar seasonal behavior to DMA and DEA though no correlation was found between MA and other amines. The average concentrations of MA, DMA and DEA for the impactor samples are summarized in Table 1 . The average mass concentrations for all three amines in December 2007 were a factor of three to six higher than in May/June 2007 independent of incoming air mass origins. In contrast, the ammonium concentrations were higher in the summer months than in the winter months with a maximum concentrations on stage $2\left(0.04-0.20 \mu \mathrm{g} \mathrm{m}^{-3}, 0.07 \mu \mathrm{g} \mathrm{m}^{-3}\right.$ average) followed by stage $3\left(0.01-0.20 \mu \mathrm{g} \mathrm{m}^{-3}, 0.05 \mu \mathrm{g} \mathrm{m}^{-3}\right.$ average) and stage $1\left(0.005-0.05 \mu \mathrm{g} \mathrm{m}^{-3}, 0.008 \mu \mathrm{g} \mathrm{m}^{-3}\right.$ average) for the summer months and $0.002-0.01 \mu \mathrm{g} \mathrm{m}^{-3}\left(0.007 \mu \mathrm{g} \mathrm{m}^{-3}\right.$ average) for stage $1,0.02-0.20 \mu \mathrm{g} \mathrm{m}^{-3}\left(0.07 \mu \mathrm{g} \mathrm{m}^{-3}\right.$ average) for stage 2 and $0.002-0.03 \mu \mathrm{g} \mathrm{m}^{-3}\left(0.007 \mu \mathrm{g} \mathrm{m}^{-3}\right.$ average) for stage 3 in the winter months. Much higher concentrations of ammonium were observed in the stage 4 and 5
Table 1. Monthly average, median, minimum and maximum aliphatic amine (MA methylamine, DMA dimethylamine, DEA diethylamine) concentrations in $\mathrm{pg} \mathrm{m}^{-3}$ detected in stage 2 Berner impactor samples, monthly average, median, minimum and maximum ammonium $\left(\mathrm{NH}_{4}^{+}\right)$concentrations in $\mathrm{ng} \mathrm{m}^{-3}$ and methane sulfonic acid concentration (MSA) in $\mu \mathrm{g} \mathrm{m}^{-3}$ detected in $\mathrm{PM}_{1.2}$ (sum of stage 1,2 , and 3 ) impactor samples ( $n=$ number of samples).

\begin{tabular}{|c|c|c|c|c|}
\hline \multicolumn{5}{|c|}{ May $2007(n=11)$} \\
\hline & Average & Median & Minimum & Maximum \\
\hline $\mathrm{MA}\left(\mathrm{pg} \mathrm{m}^{-3}\right)$ & 20 & 20 & 10 & 30 \\
\hline DMA $\left(\operatorname{pg~m}^{-3}\right)$ & 220 & 210 & 130 & 360 \\
\hline DEA $\left(\operatorname{pg~m}^{-3}\right)$ & 60 & 60 & 5 & 110 \\
\hline $\mathrm{NH}_{4}^{+}\left(\mathrm{ng} \mathrm{m}^{-3}\right)$ & 100 & 60 & 50 & 240 \\
\hline $\operatorname{MSA}\left(\mathrm{ng} \mathrm{m}^{-3}\right)$ & 7 & 5 & 0.6 & 20 \\
\hline \multicolumn{5}{|c|}{ June $2007(n=10)$} \\
\hline & Average & Median & Minimum & Maximum \\
\hline MA $\left(\mathrm{pg} \mathrm{m}^{-3}\right)$ & 60 & 30 & 10 & 120 \\
\hline DMA $\left(\operatorname{pg~m}^{-3}\right)$ & 200 & 210 & 50 & 390 \\
\hline $\operatorname{DEA}\left(\mathrm{pg} \mathrm{m}^{-3}\right)$ & 80 & 70 & 60 & 140 \\
\hline $\mathrm{NH}_{4}^{+}\left(\mathrm{ng} \mathrm{m}^{-3}\right)$ & 70 & 60 & 30 & 160 \\
\hline $\operatorname{MSA}\left(\mathrm{ng} \mathrm{m}^{-3}\right)$ & 4 & 3 & 2 & 8 \\
\hline \multicolumn{5}{|c|}{ December $2007(n=24)$} \\
\hline & Average & Median & Minimum & Maximum \\
\hline MA $\left(\operatorname{pg~m}^{-3}\right)$ & 180 & 150 & 2 & 520 \\
\hline DMA $\left(\operatorname{pg~m}^{-3}\right)$ & 570 & 540 & 100 & 1400 \\
\hline DEA $\left(\mathrm{pg} \mathrm{m}^{-3}\right)$ & 320 & 290 & 90 & 760 \\
\hline $\mathrm{NH}_{4}^{+}\left(\mathrm{ng} \mathrm{m}^{-3}\right)$ & 70 & 70 & 20 & 200 \\
\hline $\operatorname{MSA}\left(\mathrm{ng} \mathrm{m}^{-3}\right)$ & 4 & 4 & 1 & 7 \\
\hline
\end{tabular}

samples collected during winter months, most likely due to the absorption of ammonium on coarse dust particles originating from the African continent (Figs. 3 and 4).

The exact sources of the amines at the Cape Verde islands are not clear at present though high amines concentrations during algal blooms in spring and winter months support the marine biological origins of amines. The amine concentrations determined in the present study are approximately a factor of ten lower than previously reported values for the North East Atlantic (Facchini et al., 2008a). The reason for this difference may be due to lower primary productivity in the region of Cape Verde in comparison to Mace Head. The lower primary productivity is also reflected in the methanesulfonic acid (MSA) concentrations which were about a factor of eight lower in the Cape Verde samples than the values reported for Mace Head (Table 1). 


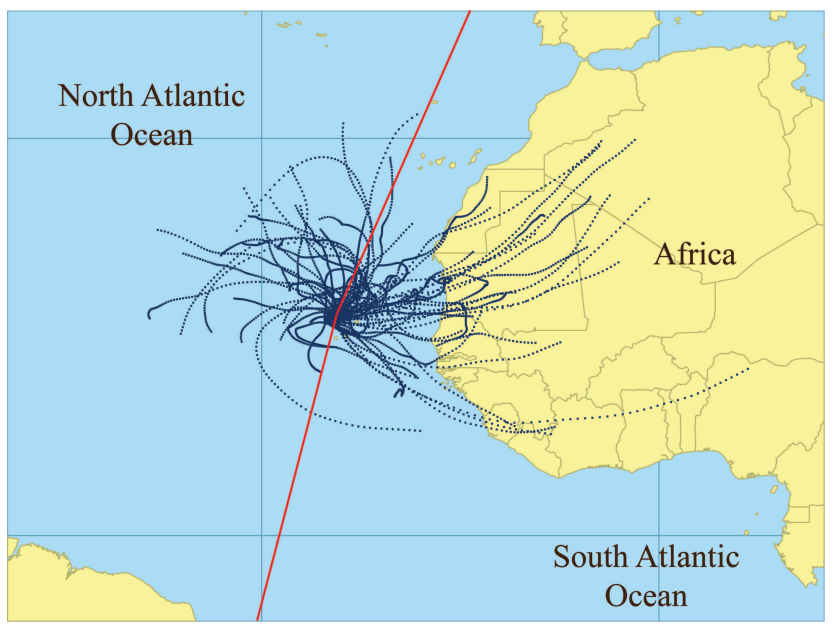

Fig. 3. Grouping of the incoming air masses in two sectors, based on backward trajectories (NOAA HYSPLIT model (Draxler and Rolph, 2003) run time $72 \mathrm{~h}$, starting height $1000 \mathrm{~m}$ ): Air masses from the North Atlantic Ocean and air masses from the African continent. Incoming flows from the Canary Islands were not considered.

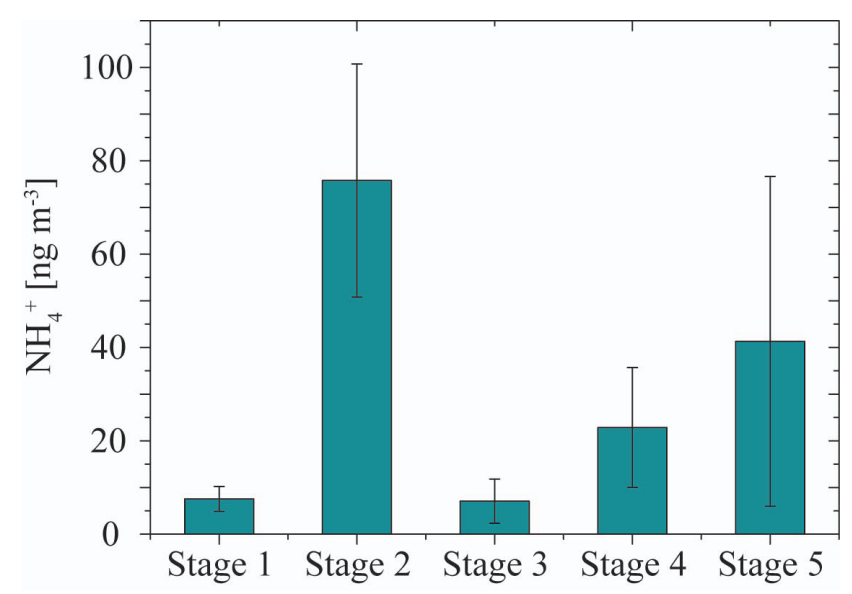

Fig. 4. Average winter ammonium concentrations for air masses originating from the African continent detected in impactor samples ( $n=19, n=$ number of samples).

Another reason is the degradation of amines during the transport from the source region to the Cape Verde islands though no evidence is found so far for the presence of degradation products. Furthermore, no correlation was found between MSA and amines for the Cape Verde samples, different from the study at the Mace Head station (Facchini et al., 2008a). The reason for this difference is not clear at this moment though it can be postulated that dimethylsulfide (DMS), a precursor of MSA, and amines might originate from different kinds of phytoplankton in the Cape Verde region than Mace Head.

\subsubsection{High volume sampling}

The particulate aliphatic amines were determined from $\mathrm{PM}_{10}$ HV samples collected from May 2007-June 2008. Monomethylamine (MA), dimethylamine (DMA), diethylamine (DEA) and morpholine (MP) were detected. Figure 5 shows the time series of the MA, DMA, DEA and MP concentrations. The most abundant amine was DMA (average $44 \%$, min $16 \%$, $\max 76 \%$ of the total amines determined) followed by DEA and MP (average 22\%, min 5\%, max 54\% and $24 \%$ average, $\min 2 \%, \max 67 \%$ ). The contribution of MA to the total detected amine concentration ranged from $0-43 \%$ with $10 \%$ on average. The concentration of DMA appears to correlate somewhat with that of DEA $(r=0.6)$. On the other hand, the concentrations of MP and MA showed no correlation with other amines though a similar seasonal variation to DMA and DEA was observed (Fig. 5). This indicates that DMA and DEA most likely originate from common sources which differ from the sources of MA and MP.

\subsubsection{Discrepancy between sampling techniques}

The detected amine concentrations in HV samples are about a factor of ten higher than in the impactor samples. Additionally, morpholine was not detected in the impactor samples at all. The reason for this discrepancy most likely originates from the absorption of gas-phase amines to the HV filter substrate (positive artifacts). Furthermore the impactor sampling can be afflicted by negative artifacts such as bounce off. Nevertheless, the amine measurements from the HV filters can be used for the indication of the seasonal amine variations because both the HV and impactor samples showed a similar seasonal trend. Furthermore, the ratios of amines determined for the HV samples are similar to those of the impactor samples.

\subsubsection{Contribution of the detected amines to the OC (or- ganic carbon) and nitrogen species in submicron particles}

Considering the fact that amines determined in the current study are only $\mathrm{C} 1$ to $\mathrm{C} 4$ compounds, the amines contribute non-negligible amounts to the total OC (Fig. S1, Supplementary Information, http://www.atmos-chem-phys.net/ 9/9587/2009/acp-9-9587-2009-supplement.pdf), ranging up to $0.5 \% \mathrm{C}$ during the summer months and $2.5 \% \mathrm{C}$ during the winter months for the stage two samples (Table 2). In comparison, the most abundant carboxylic acid (oxalic acid) contributes on average $6.9 \% \mathrm{C}$ in the summer months and average $4.4 \% \mathrm{C}$ in the winter months to the OC (Table 2). On the other hand, the contributions of the amines to the OC in the stage 3 and 4 samples did not show a strong seasonal variation indicating that only little or no amines absorption occurred into dust particles unlike ammonium for the size segregated samples collected during the winter 


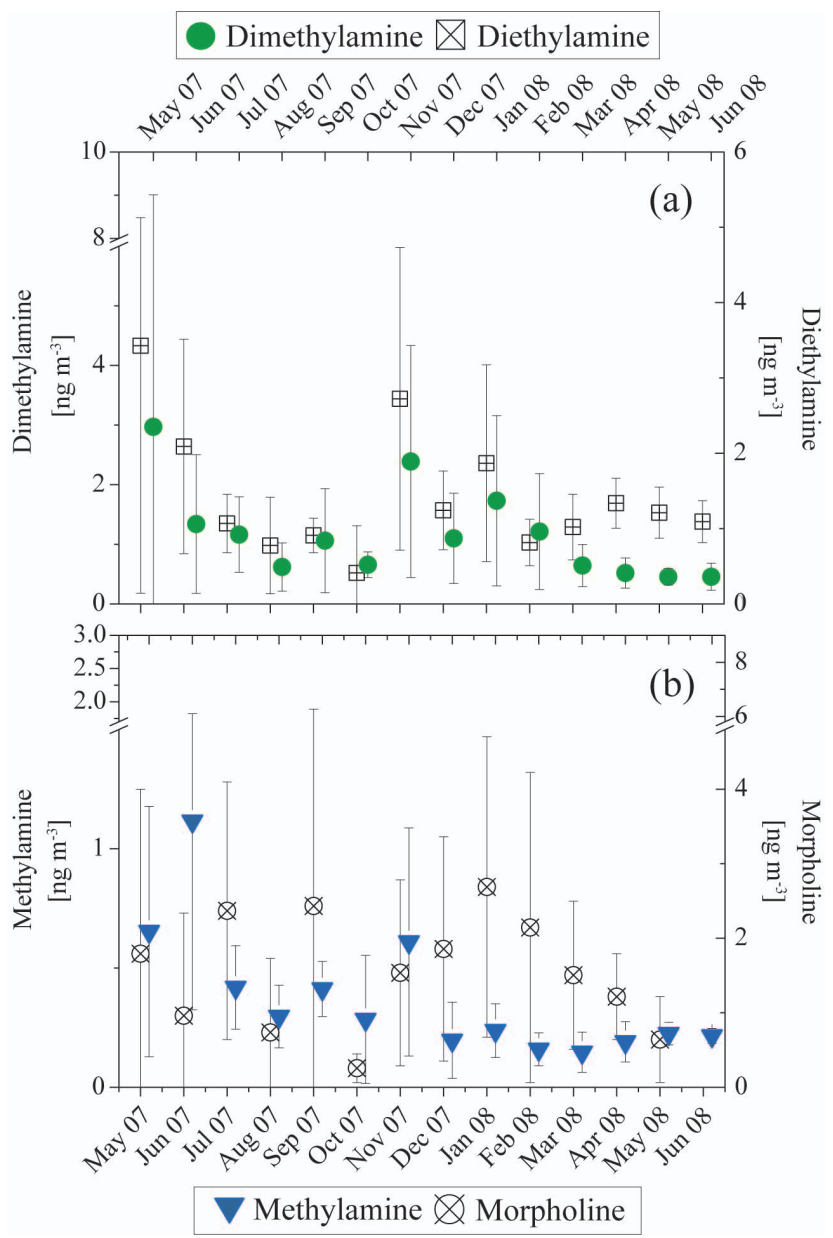

Fig. 5. (a) Monthly averages with standard deviation of dimethylamine (DMA, filled green circle) and diethylamine (DEA, crossed quarter) detected from the quartz fiber filter from a high volume sampler $\left[\mathrm{ng} \mathrm{m}^{-3}\right]$. (b) Monthly averages with standard deviation of monomethylamine (MA, filled blue triangle) and morpholine (MP, crossed circle) detected from the quartz fiber filter from a high volume sampler $\left[\mathrm{ng} \mathrm{m}^{-3}\right.$ ].

intensive campaign (Fig. 6). This is further supported by the observation that the contributions of the amines to the $\mathrm{OC}$ in the stage 3 and 4 samples did not vary dramatically regardless of the wind directions. Detailed discussions about the seasonal variation of the amines are given in Sect. 3.2.

The contributions of the determined amines to the detected nitrogen species in the stage 2 impactor samples are shown in Fig. S2 (Supplementary Information, http://www.atmos-chem-phys.net/9/9587/2009/ acp-9-9587-2009-supplement.pdf). The detected nitrogen content was calculated as a sum of the determined ammonium, nitrate and the aliphatic amines. Ammonium was the most abundant nitrogen containing species in the submicrometer particle in these samples. The amines showed non-negligible contributions to the sum parameter in

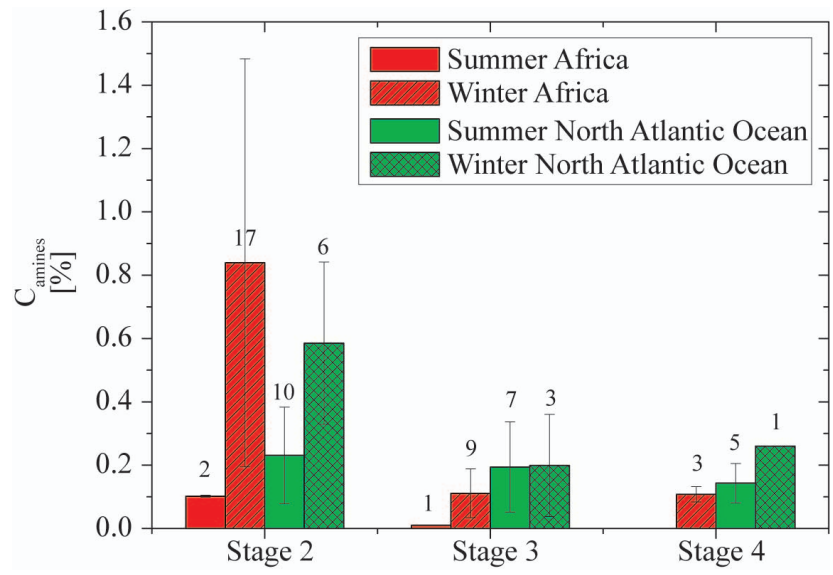

Fig. 6. The contribution (\%) of amines to the organic carbon content in stage 2, 3 and 4 impactor samples. Red colored bars show the air masses from the African continent and green bar shows the air masses from the North Atlantic Ocean. The numbers shown above the bars indicate the number of samples collected for each category.

Table 2. Percentage contribution of the amines and oxalic acid (stage 2) to the organic carbon content (OC) detected from stage 2 Berner impactor ( $n=$ number of samples).

\begin{tabular}{lcccc}
\hline \multicolumn{5}{c}{ Summer $(n=19)$} \\
\hline Carbon content (\%) & Average & Median & Minimum & Maximum \\
\hline Amines & 0.2 & 0.2 & 0.02 & 0.5 \\
Oxalic acid & 6.9 & 6.7 & 0.4 & 17.6 \\
\hline \multicolumn{5}{c}{ Winter $(n=26)$} \\
\hline Carbon content $(\%)$ & Average & Median & Minimum & Maximum \\
\hline Amines & 0.8 & 0.6 & 0.2 & 2.5 \\
Oxalic acid & 4.4 & 4.1 & 0.5 & 11.1 \\
\hline
\end{tabular}

comparison to the inorganic species for the stage 2 samples, ranging from $0.1 \% \mathrm{~N}$ to $1.5 \% \mathrm{~N}(0.8 \% \mathrm{~N}$ average and $0.7 \% \mathrm{~N}$ median) in the winter months and from $0.02 \% \mathrm{~N}-0.7 \% \mathrm{~N}$ $(0.2 \% \mathrm{~N}$ average, $0.1 \% \mathrm{~N}$ median) in the summer months. These values are comparable to the contributions of the amines to the $\mathrm{OC}$ for the stage 2 samples, indicating that the amines may have a non-trivial impact on the nitrogen cycle in the marine environment. Gibb et al. (1999) estimated the ammonia and amine cycles for the Arabian Sea and suggested that only a small amount of the marine produced amines stays in the particle phase as the large fractions of ammonia and amines are photo-oxidized or are washed away by rain. This suggests that the amines detected in this study represent only a small fraction of the amines in the nitrogen cycle of the region and aliphatic amines may play a non-negligible role in the whole nitrogen cycle beside the ammonia in the remote marine environment. 

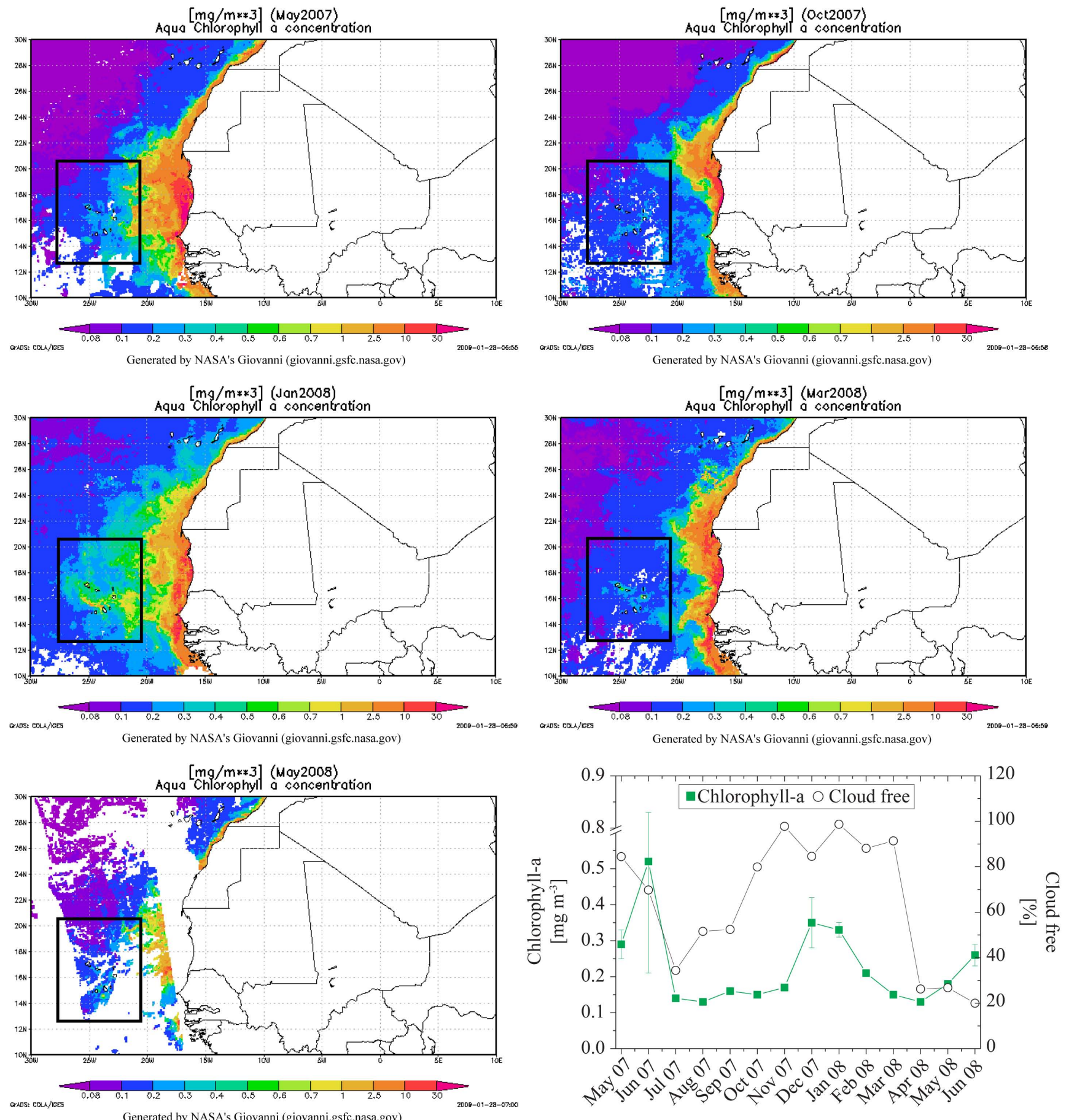

Fig. 7. Monthly modeled MODIS-Aqua satellite images from the Cape Verde Island region (Giovanni, NASA) and MODIS ocean color based time series of Chl- $a$ (chlorophyll- $a$ ) averaged over the region $12.5-20.5^{\circ} \mathrm{N} / 20.5-28.5^{\circ} \mathrm{W}$. The green filled squares are the average Chl- $a$ concentration with error bars indicating $1 / 10$ of the variability over the region, and the open black circles gives the percentage of cloud cover over the region. 


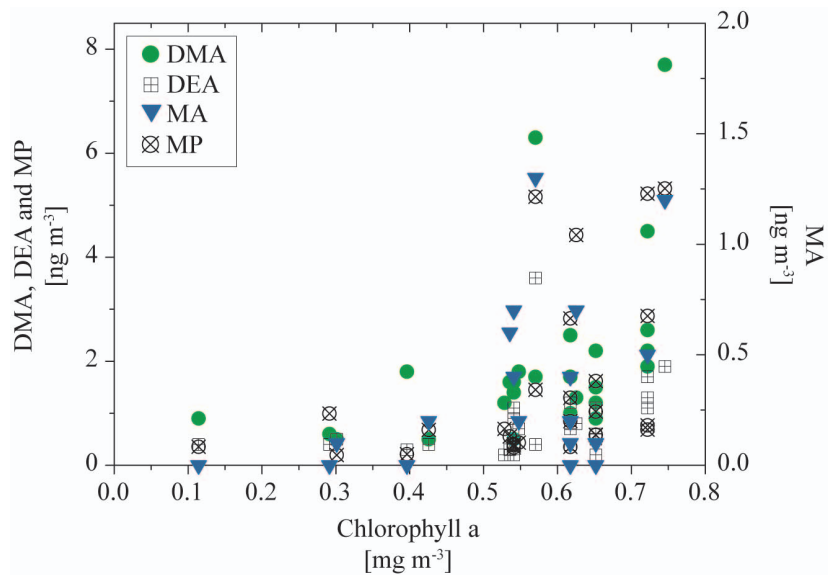

Fig. 8. DMA, DEA and MP concentrations as a function of the weekly average Chlorophyll- $a$ concentrations calculated from SeaWiFS data (OBPG SeaWiFS 8-Day Global 9-km Products; catchment area $7^{\circ}$ around the Atmospheric Observatory). No weekly chlorophyll- $a$ data were available for January 2008-March 2008. The chlorophyll- $a$ concentration was plotted against the aliphatic amines concentrations from incoming air masses from the North Atlantic Ocean (DMA filled green circle, DEA crossed quarter, MA blue filled triangle and MP crossed circle) for the samples taken with a high volume sampler.

\subsection{Seasonal variation and influencing factors}

\subsubsection{Influence of biogenic activities on seasonal variation}

The measured aliphatic amines show higher concentration in the spring 2007 and in the winter 2007/2008 than the rest of the measurement periods (Fig. 5). These high values might be connected to higher biomass production, assuming that the amines are of marine biological origin. Indeed, the MODIS data (Fig. 7) shows high chlorophyll- $a$ concentrations for May and June 2007 and December 2007 and January 2008, coinciding with higher average amine concentrations for these months (Fig. 5). It should be noted that no enhanced amine concentrations were observed during the spring 2008. Due to high cloud cover of the region during this period, no reliable MODIS Chl- $a$ data (Giovanni, NASA) is available to assess the extent of biological activity for the spring 2008 (Fig. 7). The interaction of the amines and the biomass production is reflected in the relationship between the amine concentrations and Chl- $a$ shown in Fig. 8 . Chl- $a$, used as an indicator for high bioactivity, can be determined from satellite measurements (SeaWiFS weekly averages, catchment area $7^{\circ}$ around the Atmospheric Observatory) and correlated with amine concentrations. To be independent from continental influences, only samples with air masses originating from the North Atlantic Ocean (see Fig. 3) are considered. The concentrations of amines tend to increase with increasing Chl- $a$ content (Fig. 8), strongly

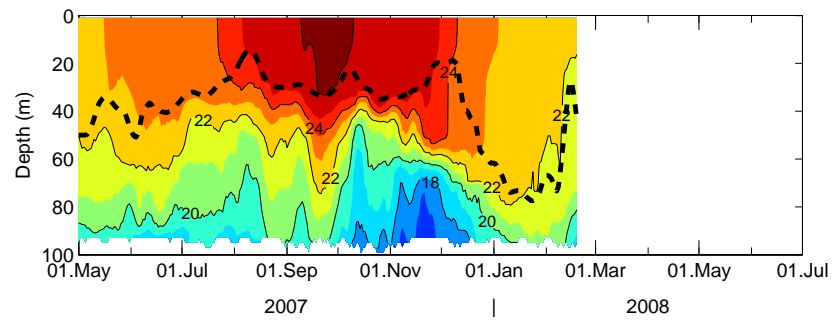

Fig. 9. Temporal evolution of the upper ocean temperature structure based on moored instruments from the TENATSO Ocean Observatory and merged with AMSR-E satellite sea surface data. The broken line indicates the depth of the mixed layer base. Contours are given for every $2^{\circ} \mathrm{C}$, color coding is every $1^{\circ} \mathrm{C}$. The mooring was recovered by the end of February 2008.

indicating the marine biogenic origin of aliphatic amines determined in this study.

\subsubsection{Local upwelling}

The marine bioproductivity is expected to be high in spring and low in the winter time. However, the satellite images show a strong algal bloom at the Cape Verde region in the winter 2007/2008. This algal bloom was most likely supported by nutrient input to the ocean surface water. In this region two mechanisms can increase the available nutrient content in the surface water. One is the upwelling and the other is the dust deposition which might foster increased biological activity by enhanced nutrient supply.

A nutrient level in the surface water around the Cape Verde islands is generally low and so as the primary productivity. Only during certain periods of the year nutrients are brought up to the surface water from deeper ocean. There are two physical processes for upwelling: (1) the local upwelling effect through the divergence of the wind field and (2) the supply of nutrients through entrainment of nutrient rich water during the phases of mixed layer deepening. We will use surface Chl- $a$ as a proxy for primary productivity (Fig. 7) as a qualitatively good correlation between primary productivity and near surface Chl- $a$ concentrations has been shown to exists (e.g. Behrenfeld and Falkowski, 1997). In the Cape Verde region the Chl- $a$, and hence the primary productivity, normally increases in late spring/early summer as a result of enhanced wind driven upwelling. The upwelling induced entrainment of nutrients is typically associated with a shallow mixed layer as water is brought up to the surface. However, for the year 2007/2008, high Chl- $a$ levels appeared also in the winter months, from December 2007 to February 2008. This is the period when the enhanced amines have been found (Fig. 5, Table 1). The temporal temperature evolution of the mixed layer is closely examined to further investigate the reason for enhanced primary productivity in the winter months. Daily averages of temperature data from moored instruments from the Cap Verde Ocean 


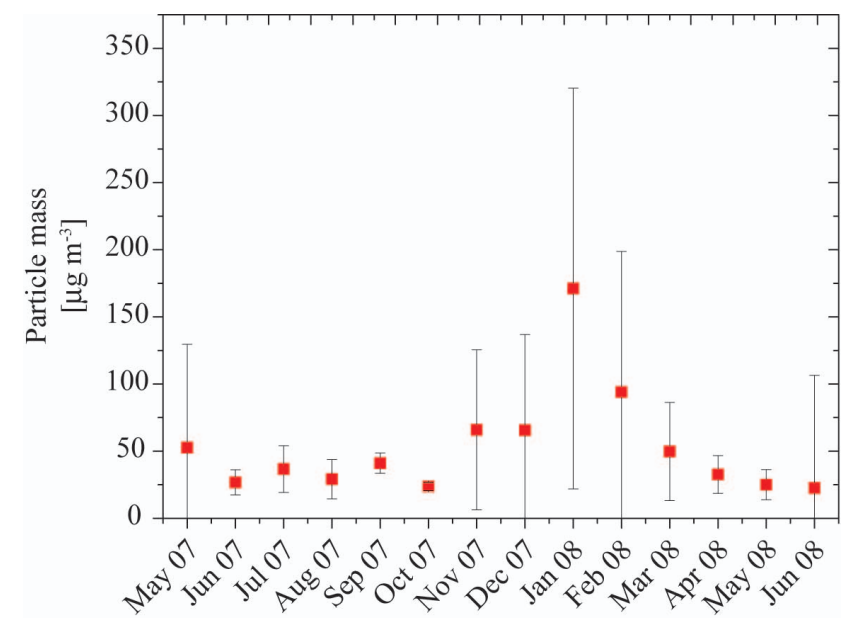

Fig. 10. Monthly average and variability of the particle mass in $\mu \mathrm{g} \mathrm{m}^{-3}$ from the quartz fiber filters taken with a high volume sampler.

Observatory are combined with satellite derived SST data. Small scale variability was removed by applying a one-week running mean to the gridded data (Fig. 9). The ocean mixed layer (ML) base was derived as the depth where the surface temperature had decreased by $0.36^{\circ} \mathrm{C}$. The temporal evolution of the ML shows a pronounced seasonal cycle with the shallowest depth (order $30 \mathrm{~m}$ ) in the summer months (JulySeptember) and the deepest ML depth in the winter months from January-March. Shorter time variability is likely the result of advection of temperature anomalies and local air-sea interaction. In particular, the ML base decreased by about $50 \mathrm{~m}$ very rapidly from end of November 2007 until middle of January 2008. The strong deepening is most likely the result of intense buoyancy loss of the surface water through enhanced evaporation and cooling. This deepening may have been associated with entrainment of colder, nutrient rich water from below which may have fuelled primary productivity. Indeed, similar anomalies with high biomass production in winter have been reported from field experiments in this Mauritanian upwelling region (Bricaud et al., 1987; Pradhan et al., 2006), in which the upwelling process was thought to be responsible for algal blooms.

\subsubsection{Dust deposition}

Another form of nutrient input during the winter months is a dust deposition process (Moor et al., 2006; Pradhan et al., 2006; Jo et al., 2006). In this respect, the nutrient input by dust was simulated by Coale et al. (1996) and Martin et al. (1994) in field experiments, demonstrating the enhanced primary productivity from the increase in biologically available iron in the ocean surface. During the field campaign, the islands were subjected to strong dust plumes in the winter months and much higher average particle mass concentrations were observed between November 2007 and Febru- ary 2008 with a peak in January 2008 (Fig. 10). Especially high mass concentrations were observed on 10 May 2007 (331 $\left.\mu \mathrm{g} \mathrm{m}^{-3}\right)$, 31 December $2007\left(339 \mu \mathrm{g} \mathrm{m}^{-3}\right)$ and 29 January $2008\left(601 \mu \mathrm{g} \mathrm{m}^{-3}\right)$. Backward trajectories show the North African origins of the air masses for these three days, indicating Saharan dust events. This is further supported by EUMETSAT images (copyright by EUMESAT2007) showing sandstorm events for these days. It is likely that the anomalous algal bloom in the winter 2007/2008 was related to both, entrainment of nutrient into the oceanic mixed layer as well as dust deposition from the atmosphere.

\section{Summary}

The concentrations of aliphatic amines were determined at the Cape Verde Atmospheric Observatory on the Island São Vicente during a one year field campaign between May 2007 and June 2008. The highest amine concentrations were determined in fine particles (impactor stage 2, $0.14-0.42 \mu \mathrm{m})$, suggesting the formation of amines in the particle phase through the reaction of gas-phase amines with acidic sub-micrometer particles. Moreover, elevated levels of amines were observed in spring and winter months which coincided with high near surface Chl- $a$ concentrations derived from ocean color satellites, indicating high primary production. The high primary productivity in the summer months may be connected to the upwelling process bringing nutrient rich deep sea water to the surface while high winter Chl- $a$ may be associated with intense mixed layer deepening which entrained nutrient rich water into the upper water layer. Moreover, Saharan dust deposition during the summer and notably the winter months may provide nutrients to the surface water. It can not be concluded from our data whether the atmospheric or the oceanic processes played the most important role for the nutrient supply. Further research is warranted for better understandings of the particle-phase amine origins, parameters controlling the formation of amines in sub-micrometer particles and the role of particle-phase amines in the ocean-atmosphere nitrogen cycle.

Acknowledgements. AMSR-E data are produced by Remote Sensing Systems and provided by the NASA Earth Science MEaSUREs DISCOVER Project and the AMSR-E Science Team. Data are available at http://www.remss.com, MODIS Chlorophyll- $a$ data is provided courtesy of the NASA Goddard Space Flight Center, Oceancolor website.

This study is partially funded by the German Federal Ministry of Education and Research (BMBF) in the project SOPRAN (Surface Ocean Processes in the Anthropocene) under contract number 03F0462J and the European Union in the TENATSO (Tropical Eastern North Atlantic Time-Series Observatory) project under contact number 037090.

Edited by: G. McFiggans 


\section{References}

Arimoto, R., Duce, R. A., Savoie, D. L., and Prospero, J. M.: TraceElements in Aerosol-Particles from Bermuda and BarbadosConcentrations, Sources and Relationships to Aerosol Sulfate, J. Atmos. Chem., 14, 439-457, 1992.

Arnold, S. R., Spracklen, D. V., Williams, J., Yassaa, N., Sciare, J., Bonsang, B., Gros, V., Peeken, I., Lewis, A. C., Alvain, S., and Moulin, C.: Evaluation of the global oceanic isoprene source and its impacts on marine organic carbon aerosol, Atmos. Chem. Phys., 9, 1253-1262, 2009,

http://www.atmos-chem-phys.net/9/1253/2009/.

Barsanti, K. C., McMurry, P. H., and Smith, J. N.: The potential contribution of organic salts to new particle growth, Atmos. Chem. Phys., 9, 2949-2957, 2009,

http://www.atmos-chem-phys.net/9/2949/2009/.

Behrenfeld, M. J. and Falkowski, P. G.: Photosynthetic rates derived from satellite-based chlorophyll concentration, Limnol. Oceanogr., 42, 1-20, 1997.

Blanchard, D. C.: Bursting of Bubbles at an Air Water Interface, Nature, 173, 1048-1048, 1954.

Bond, T. C., Streets, D. G., Yarber, K. F., Nelson, S. M., Woo, J. H., and Klimont, Z.: A technology-based global inventory of black and organic carbon emissions from combustion, J. Geophys. Res.-Atmos., 109, D14203, doi:10.1029/2003JD003697, 2004.

Bricaud, A., Morel, A., and Andreè, J. M.: Spatial/temporal variability of algal biomass and potential productivity in the Mauritanian upwelling zone, as estimated from CZCS data, Adv. Space. Res., 7, 53-62, 1987.

Cavalli, F., Facchini, M. C., Decesari, S., Mircea, M., Emblico, L., Fuzzi, S., Ceburnis, D., Yoon, Y. J., O’Dowd, C. D., Putaud, J. P., and Dell'Acqua, A.: Advances in characterization of size-resolved organic matter in marine aerosol over the North Atlantic, J. Geophys. Res.-Atmos., 109, D24215, doi:10.1029/2004JD005137, 2004.

Coale, K. H., Johnson, K. S., Fitzwater, S. E., Gordon, R. M., Tanner, S., Chavez, F. P., Ferioli, L. Sakamoto, C., Rogers, P.. Millero, F., Steinberg, P., Nightingale, P., Cooper, D., Cochlan, W. P., Landry, M. R., Constantinou, J., Rollwagen, G., Trasvina, A., and Kudela, R.: A massive phytoplankton bloom induced by an ecosystem-scale iron fertilization experiment in the equatorial Pacific Ocean, Nature, 383, 495-501, 1996.

Cooke, W. F., Liousse, C., Cachier, H., and Feichter, J.: Construction of a 1 degrees $\times 1$ degrees fossil fuel emission data set for carbonaceous aerosol and implementation and radiative impact in the ECHAM4 model, J. Geophys. Res.-Atmos., 104, 2213722162, 1999.

Cornell, S., Mace, K., Coeppicus, S., Duce, R., Huebert, B., Jickells, T., and Zhuang, L. Z.: Organic nitrogen in Hawaiian rain and aerosol, J. Geophys. Res.-Atmos., 106, 7973-7983, 2001.

Draxler, R. R. and Rolph, G. D.: HYSPLIT (HYbrid Single-Particle Lagrangian Integrated Trajectory) Model access via NOAA ARL READY Website (http://www.arl.noaa.gov/ready/hysplit4.html), NOAA Air Resources Laboratory, Silver Spring, MD, USA, 2003.

Facchini, M. C., Decesari, S., Rinaldit, M., Carbone, C., Finessi, E., Mircea, M., Fuzzi, S., Moretti, F., Tagliavini, E., Ceburnis, D., and O'Dowd, C. D.: Important source of marine secondary organic aerosol from biogenic amines, Environ. Sci. Technol.,
42, 9116-9121, 2008a.

Facchini, M. C., Rinaldi, M., Decesari, S., Carbone, C., Finessi, E., Mircea, M., Fuzzi, S., Ceburnis, D., Flanagan, R., Nilsson, E. D., de Leeuw, G., Martino, M., Woeltjen, J., and O'Dowd, C. D.: Primary submicron marine aerosol dominated by insoluble organic colloids and aggregates, Geophys. Res. Lett., 35, L17814, doi:10.1029/2008GL034210, 2008b.

Fitzgerald, J. W.: Marine aerosols - a review, Atmos. Environ. AGen., 25, 533-545, 1991.

Gantt, B., Meskhidze, N., and Kamykowski, D.: A new physicallybased quantification of marine isoprene and primary organic aerosol emissions, Atmos. Chem. Phys., 9, 4915-4927, 2009, http://www.atmos-chem-phys.net/9/4915/2009/.

Gibb, S. W., Mantoura, R. F. C., and Liss, P. S.: Ocean-atmosphere exchange and atmospheric speciation of ammonia and methylamines in the region of the NW Arabian Sea, Global. Biogeochem. Cy., 13, 161-177, 1999.

Healy, R. M., Wenger, J. C., Metzger, A., Duplissy, J., Kalberer, M., and Dommen, J.: Gas/particle partitioning of carbonyls in the photooxidation of isoprene and 1,3,5-trimethylbenzene, Atmos. Chem. Phys., 8, 3215-3230, 2008,

http://www.atmos-chem-phys.net/8/3215/2008/.

Hoffman, E. J. and Duce, R. A.: Factors Influencing OrganicCarbon Content of Marine Aerosols - Laboratory Study, J. Geophys. Res.-Oc. Atm., 81, 3667-3670, 1976.

Hoffman, E. J. and Duce, R. A.: Organic Carbon Content of Marine Aerosols Collected on Bermuda, J. Geophys. Res., 79, 44744477, 1974.

Iinuma, Y., Brüggemann, E., Gnauk, T., Müller, K., Andreae, M. O., Helas, G., Parmar, R., and Herrmann, H.: Source characterization of biomass burning particles: The combustion of selected European conifers, African hardwood, savanna grass, and German and Indonesian peat, J. Geophys. Res., 112, D08209, doi: 10.1029/2006JD007120, 2007.

IPCC (Intergovernmental Panel on Climate Change: Climate Change 2007): Synthesis Report, Contribution of Working Groups I, II and III to the Fourth Assessment Report of the Intergovernmental Panel on Climate Change, edited by: Core Writing Team: Pachauri, R. K. and Reisinger, A., Geneva, Switzerland, 2007.

Jo, C. O., Lee, J. Y., Park, K. A., Kim, Y. H., and Kim, K. R.: Asian dust initiated early spring bloom in the northern East/Japan Sea, Geophys. Res. Lett., 34, L05602, doi:10.1029/2006GL027395, 2007.

Kawamura, K. and Gagosian, R. B.: Implications of OmegaOxocarboxylic Acids in the Remote Marine Atmosphere for Photooxidation of Unsaturated Fatty-Acids, Nature, 325, 330-332, 1987.

Kawamura, K. and Gagosian, R. B.: Midchain Ketocarboxylic Acids in the Remote Marine Atmosphere - Distribution Patterns and Possible Formation Mechanisms, J. Atmos. Chem., 11, 107$122,1990$.

Kawamura, K. and Sakaguchi, F.: Molecular distributions of water soluble dicarboxylic acids in marine aerosols over the Pacific Ocean including tropics, J. Geophys. Res.-Atmos., 104, 35013509, 1999.

Knelman, F., Dombrowski, N., and Newitt, D. M.: Mechanism of the Bursting of Bubbles, Nature, 173, 261-261, 1954.

Kulmala, M.: How particles nucleate and grow, Science, 302, 1000- 
1001, 2003.

Kulmala, M. and Kerminen, V. M.: On the formation and growth of atmospheric nanoparticles, Atmos. Res., 90, 132-150, 2008.

Kurtén, T., Loukonen, V., Vehkamäki, H., and Kulmala, M.: Amines are likely to enhance neutral and ion-induced sulfuric acid-water nucleation in the atmosphere more effectively than ammonia, Atmos. Chem. Phys., 8, 4095-4103, 2008, http://www.atmos-chem-phys.net/8/4095/2008/.

Kuznetsova, M., Lee, C., and Aller, J.: Characterization of the proteinaceous matter in marine aerosols, Mar. Chem., 96, 359-377, 2005.

Mårtensson, E. M., Nilsson, E. D., de Leeuw, G., Cohen, L. H., and Hansson, H. C.: Laboratory simulations and parameterization of the primary marine aerosol production, J. Geophys. Res., 108(D9), 4297, doi:10.1029/2002JD002263, 2003.

Martin, J. H., Coale, K. H., Johnson, K. S., Fitzwater, S. E., Gordon, R. M., Tanner, S. J., Hunter, C. N., Elrod, V. A., Nowicki, J. L., Coley, T. L., Barber, R. T., Lindley, S., Watson, A. J., Vanscoy, K., Law, C. S., Liddicoat, M. I., Ling, R., Stanton, T., Stockel, J., Collins, C., Anderson, A., Bidigare, R., Ondrusek, M., Latasa, M., Millero, F. J., Lee, K., Yao, W., Zhang, J. Z., Friederich, G., Sakamoto, C., Chavez, F., Buck, K., Kolber, Z., Greene, R., Falkowski, P., Chisholm, S. W., Hoge, F., Swift, R., Yungel, J., Turner, S., Nightingale, P., Hatton, A., Liss, P., Tindale, N. W.: Testing the iron hypothesis in ecosystems of the equatorial Pacific-Ocean, Nature, 371, 123-129, 1994.

Matsumoto, K. and Uematsu, M.: Free amino acids in marine aerosols over the western North Pacific Ocean, Atmos. Environ., 39, 2163-2170, 2005.

Mochida, M., Kawabata, A., Kawamura, K., Hatsushika, H., and Yamazaki, K.: Seasonal variation and origins of dicarboxylic acids in the marine atmosphere over the western North Pacific, J. Geophys. Res.-Atmos., 108(D6), 4193, doi:10.1029/2002JD002355, 2003.

Mochida, M., Kawamura, K., Umemoto, N., Kobayashi, M., Matsunaga, S., Lim, H. J., Turpin, B. J., Bates, T. S., and Simoneit, B. R. T.: Spatial distributions of oxygenated organic compounds (dicarboxylic acids, fatty acids, and levoglucosan) in marine aerosols over the western Pacific and off the coast of East Asia: Continental outflow of organic aerosols during the ACE-Asia campaign, J. Geophys. Res.-Atmos., 108(D23), 8638, doi:10.1029/2002JD003249, 2003.

Moore, C. M., Mills, M. M., Milne, A., Langlois, R., Achterberg, E. P., Lochte, K., Geider, R., J., and La Roche, J.: Iron limits primary productivity during spring bloom development in the central North Atlantic, Glob. Change Biol., 12, 626-634, 2006.

Mopper, K. and Zika, R. G.: Free Amino-Acids in Marine Rains Evidence for Oxidation and Potential Role in Nitrogen Cycling, Nature, 325, 246-249, 1987.

National Aeronautics and Space Administration (NASA), Goddard Earth Sciences Data and Information Services Center, Giovanni, available at: http://disc.sci.gsfc.nasa.gov/giovanni/, 2009.

Neusüß, C., Pelzing, M., Plewka, A., and Herrmann, H.: A new analytical approach for size-resolved speciation of organic compounds in atmospheric aerosol particles: Methods and first results, J. Geophys. Res., 105, 4513-4527, 2000.
O’Dowd, C. D., Langmann, B., Varghese, S., Scannell, C., Ceburnis, D., and Facchini, M. C.: A combined organic-inorganic sea-spray source function, Geophys. Res. Lett., 35, L01801, doi:10.1029/2007GL030331, 2008.

O’Dowd, C. D., Facchini, M. C., Cavalli, F., Ceburnis, D., Mircea, M., Decesari, S., Fuzzi, S., Yoon, Y. J., and Putaud, J. P.: Biogenically driven organic contribution to marine aerosol, Nature, 431, 676-680, 2004.

O'Dowd, C. D. and Smith, M. H.: Physicochemical Properties of Aerosols over the Northeast Atlantic - Evidence for WindSpeed-Related Submicron Sea-Salt Aerosol Production, J. Geophys. Res., 98(D1), 1137-1149, 1993.

Pradhan, Y., Lavender, S. J., Hardman-Mountford, N. J., and Aiken, J.: Seasonal and inter-annual variability of chlorophyll-a concentration in the Mauritanian upwelling, Observation of an anomalous event during 1998-1999, Deep-Sea Res. Pt. II, 53, 15481559, 2006.

Raemdonck, H., Maenhaut, W., and Andreae, M. O.: Chemistry of Marine Aerosol over the Tropical and Equatorial Pacific, J. Geophys. Res.-Atmos., 91, 8623-8636, 1986.

Resch, F. and Afeti, G.: Submicron Film Drop Production by Bubbles in Seawater, J. Geophys. Res., 97(C3), 3679-3683, 1992.

Roelofs, G. J.: A GCM study of organic matter in marine aerosol and its potential contribution to cloud drop activation, Atmos. Chem. Phys., 8, 709-719, 2008, http://www.atmos-chem-phys.net/8/709/2008/.

Sicre, M. A., Marty, J. C., and Saliot, A.: N-Alkanes, Fatty-Acid Esters, and Fatty-Acid Salts in Size Fractionated Aerosols Collected over the Mediterranean-Sea, J. Geophys. Res.-Atmos., 95, 3649-3657, 1990.

Spracklen, D. V., Arnold, S. R., Sciare, J., Carslaw, K. S., and Pio, C.: Globally significant oceanic source of organic carbon aerosol, Geophys. Res. Lett., 35, L12811, doi:10.1029/2008GL033359, 2008.

van Neste, A., Duce, R. A., and Lee, C.: Methylamines in the Marine Atmosphere, Geophys. Res. Lett., 14, 711-714, 1987.

Wang, H. B., Kawamura, K., and Yamazaki, K.: Water-soluble dicarboxylic acids, ketoacids and dicarbonyls in the atmospheric aerosols over the Southern Ocean and western Pacific Ocean, J. Atmos. Chem., 53, 43-61, 2006.

Woodcock, A. H., Kientzler, C. F., Arons, A. B., and Blanchard, D. C.: Giant Condensation Nuclei from Bursting Bubbles, Nature, 172, 1144-1145, 1953.

Yoon, Y. J., Ceburnis, D., Cavalli, F., Jourdan, O., Putaud, J. P., Facchini, M. C., Decesari, S., Fuzzi, S., Sellegri, K., Jennings, S. G., and O'Dowd, C. D.: Seasonal characteristics of the physicochemical properties of North Atlantic marine atmospheric aerosols, J. Geophys. Res.-Atmos., 112, D04206, doi:10.1029/2005JD007044, 2007. 